\title{
Physiological quality of soybean seeds in fixed-bed dryer with air radial distribution
}

\author{
Séfora SILVÉRIO ${ }^{1}$, Arlindo Modesto ANTUNES ${ }^{2}$, Rafael Batista FERREIRA ${ }^{3}$, Daniel Antônio da CUNHA ${ }^{3}$, \\ Ivano Alessandro DEVILLA ${ }^{3}$, Rosilane Carvalho da CONCEIÇÃO
}

\author{
${ }^{1}$ National Supply Company, Brasília, Federal District, Brazil \\ ${ }^{2}$ Department of Agricultural Engineering, Federal Rural University of Amazônia, Tomé-Açu, Pará, Brazil \\ ${ }^{3}$ Department of Agricultural Engineering, State University of Goiás, Goiás, Anápolis, Brazil
}

\section{*Corresponding author: arlindo.modesto1@hotmail.com}

\begin{abstract}
In recent years few countries have grown as much in international agribusiness trade as in Brazil, where soybean (Glycine max (L.) Merrill) is one of the economic activities that have contributed most. However, in order to increase or maintain the efficiency of the oilseed, it is necessary to increase the knowledge in the post-harvest techniques that are applied to the seeds to maintain their quality. This study aimed at evaluation of the physiological quality and the drying uniformity of soybean seeds in a commercial fixed-bed dryer of the brand Granfinale and industrial ventilator of the brand AeroMack with the radial distribution of air. Samples were collected at 4 vertical heights: $0.20,1.40,2.60$ and 3.80 meters at the dryer base combined with 4 radial distances of 0.15 , 0.30, 0.45 and 0.60 meters and central duct, through a $4 \times 4$ random factorial scheme. The following analyzes were performed on seeds: Water Content (WC), Germination Standard Test (GST), First count of Germination Standard Test (FCT), Accelerated Aging (AA), Electric Conductivity (EC) and Germination Velocity Index (GVI). The analysis of variance and regression analysis were performed, when applicable. We found a super drying in the lower layer and retardation in the upper layer of stationary drying. The seeds located at vertical heights of 0.20 and $1.40 \mathrm{~m}$ obtained the highest mean values of Germination Standard Test and Accelerated Aging. On the other hand, seeds located at vertical heights of $0.20 \mathrm{~m}$, regardless of radial distances, showed less vigor according to Electric Conductivity test in relation to the other treatments. The variables First count of Germination Standard Test (FCT) and Germination Velocity Index (GVI) were not significantly influence by the evaluated treatments and their interaction.
\end{abstract}

Key words: Drying stationary, Glycine Max (L.) Merrill, Viability, Vigor.

Abbreviations: AA_accelerated aging; CV_variation coefficient; EC_electric conductivity; FCT_germination standard test; GST_germination standard test; GVI_germination velocity index; m_meters; WC_Water Content

Introduction

In the context of global agribusiness, soybean production (Glycine max (L.) Merrill) is among the economic activities that in the last decades presented the most expressive growth (Dall'agnol et al., 2010). A few countries in international agribusiness trade have grown as much as Brazil and soybean production is one of the economic activities that contributed the most for those (Dall'agnol et al., 2010; Almeida et al., 2013). Its exploration began in the south and today it is already found in the most different environments, portrayed by the advance of cultivation mainly in the central region of the country (Freitas, 2011b). Therefore, soybean is currently a subject of intense research activity aimed at obtaining information that allows for increases in productivity. In this context, the use of high quality seeds constitutes a tool of extreme importance for the farmer (Freitas et al., 2011a). Peske and Villela (2003) added that in order for there to be continuous expansion of soybean cultivation in Brazil, it is necessary to use high quality seeds for the proper establishment of plants in the field to avoid higher production costs.
Seed quality is mainly related to the capacity of germination, viability and vigor to perform its vital functions. So, the effects on seed quality depend on the physiological potential and are generally translated by the decrease in the percentage of germination, increase of abnormal seedlings and reduction of vigor of the seedlings (Carvalho and Nakeagawa, 2000).

However, the production of high-quality soybeans is a challenge for the sowing sector, especially in tropical and subtropical regions (Krzyzanowski et al., 2008a). This task is more complex compared to other cultivated plants, because soybean seeds are characterized by great sensitivity to mechanical agents, pathogens and climatic conditions (Marcos filho et al., 1986). The Soybeans should be harvested at the right time, avoiding any delay in harvesting. They are usually harvested when the water content is below $18 \%$ b. u., during the natural drying process in the field (Peske et al., 2003). Even after reaching adequate water content for mechanical harvesting, seeds from the field generally have inadequate water content for safe storage, 
which may accelerate the deterioration process during storage (Avelar et al., 2011).

As a result, knowledge about artificial drying of the harvested material is indispensable, so that the water content obtained allows adequate storage (Miranda et al., 1999). Thus, the drying of seeds requires the compatibility between the operational procedures regarding the physical yield of the process (Cavariani et al., 1998). The poor use of the drying techniques causes enormous problems in the loss of the product, mainly due to deterioration during storage, high respiration rate and the occurrence of thermal damages caused by high temperatures (Eiras, 2013).

Among the dryers most commonly used for seeds is the stationary type, or fixed-bed dryer, where hot air is forced through the seeds transversely through a centrally perforated cylinder. Carvalho and Nakagawa (2000) noted the bed dryer as preferred machine because it does not cause mechanical damages to the seeds, due to non-mass movement during drying. However, this model of dryer presents problems regarding the uniformity of seed moisture in occurrence of regions with lower static pressure. Three reasons can be identified: (1) greater air flow in the lower part of the dryer, resulting in a higher drying rate of the seeds in the lower layers; (2) improper positioning of the valve located inside the central tube; (3) leveling the seed coat at the top of the dryer, causing the seeds at the periphery not to receive sufficient airflow to dry. Thus, the objective of this study was to evaluate the physiological quality of soybean seeds located in different regions in the fixed-bed dryer with radial air distribution. In here, we concluded that the seeds located at lower vertical heights present higher germination and vigor mean and seeds located at a lower vertical height $(0.2 \mathrm{~m})$ presented less vigor when the electrical conductivity test was used.

\section{Results and discussion}

\section{Analysis of variance}

Table 1 shows the summary of the variance analysis of parameters evaluated in function of treatments. We found that vertical distance influenced the GST, AA, EC and WC tests. Radial distance influenced only the WC. Interaction between the treatments influenced the EC and WC tests. The variables FCT and GVI were not significantly influenced by the evaluated treatments and their interaction. Regarding the coefficient of variation (CV), all variables presented high experimental precision according to criteria established by Pimental Gomes (2002).

\section{Water content}

In relation to the WC of soybean seeds from the vertical and radial distances of the fixed bed dryer, vertical distances of $0.20 \mathrm{~m}$ and $1.40 \mathrm{~m}$ provided lower values of this variable, regardless of the radial distance. It shows unevenness in seed drying in this type of dryer (Figure 1). The values of the equation coefficients generated for WC at each radial distance and their respective determination coefficients $\left(R^{2}\right)$ in can be seen in Table 2.
Antunes et al. (2016), analyzed the physical behavior of stationary drying with axial distribution of air in corn seed drying. Garcia et al. (2001) and Huttunen et al. (2017) obtained similar results, when evaluated the effects of artificial drying on the physiological quality of wheat seeds and bark using stationary drying. In perforated central cylinder, Avelar et al. (2011); Miranda et al. (1999); Cavariani et al. (1999), also noted absence of seed mass uniformity. The largest variation in water content between the silo wall and the central drilling cylinder was recorded at the shortest vertical distance $(0.20 \mathrm{~m})$, the closest section to hot air flow. At this location, an average of $11.85 \%$ (bu) was found in the radial distance of $0.15 \mathrm{~m}$ and $12.38 \%$ (bu) at $0.60 \mathrm{~m}$ in relation to the central duct, with a variation of 0.53 percentage points processed). This behavior was occurred because the seeds are hygroscopic and seek balance with the medium (Carvalho and Nakagawa, 2000). The water flow from the interior to the seed surface occurs, due to water and the thermal gradient between these two regions, when submitted to artificial drying. The increase of air temperature decreases relative humidity, reducing its water retention capacity (Avelar et al., 2012; Peske and Villela, 2003). Miranda et al. (1999), analyzed the physical behavior of soybean seeds and verified that at different radial distances, temperatures increased with the advancement of the drying time, in magnitudes that augment with the approach to the inflation cylinder. Pasin (1991) observed a difference of $15{ }^{\circ} \mathrm{C}$ in the temperature gradient between the central all and the external wall of the dryer. Levien (2005) showed a difference of 3 percentage points in the water content, demonstrating that the seeds near the central core are superheated. Another notable feature is on the vertical heights of $0.20 \mathrm{~m}$ and $1.40 \mathrm{~m}$ and radial distance of $0.30 \mathrm{~m}$ which provided close values $(10.66 \%$ and $10.70 \%$, without transformation). Those that are closer to the central cylinder $(0.15 \mathrm{~m})$ are mainly lower. One of the possible justifications for this would be the permanence of seeds in the field, or even the location inside the trucks, where they are closer to upper regions and receive greater solar irradiation (França neto et al. 2010). In general, the highest recorded water content was $13.85 \%$ (b.u.) in the vertical distance of $2.60 \mathrm{~m}$ and radial of $0.30 \mathrm{~m}$. The lowest was $10.66 \%$ in the vertical distance of $0.20 \mathrm{~m}$ and radial of $0.30 \mathrm{~m}$, respectively (untransformed data). Many factors alter the dissipation and uniformity of the drying air such as seed positioning in the hot air flow, protective cover of the same, ducts architecture and porous spaces, uniformity of mass and thickness of the seed layer (Moraes, 2000; Peske e Villela, 2003; Silva et al., 2008). Pasin (1991) stated that this difference in the gradient tends to disappear by the action of layered discharge system, developed for this type of dryer. This guarantees seed mass homogenization.

\section{Germination standard test and accelerated aging}

In relation to GST, we observed (Figure 2 ) that the vertical distances of $0.20 \mathrm{~m}$ and $1.40 \mathrm{~m}$ were the ones that caused the highest average values of $91.62 \%$ and $93.12 \%$, respectively (untransformed data). 
Table 1. Summary of variance analysis from mean germination values (GST), first count of germination standard test (FCT), accelerated aging (AA), electrical conductivity (EC), germination speed index (GSI) and water content (WC) of soybean seeds subjected to drying at different locations within a fixed-bed dryer with radial air distribution.

\begin{tabular}{llllllll}
\hline \multirow{2}{*}{ FV } & \multirow{2}{*}{$\mathrm{GL}$} & \multicolumn{5}{c}{ QM } \\
\cline { 3 - 8 } & & GST & FCT & AA & EC & GVI & WC \\
\hline Vertical distance (A) & 3 & $146.871^{*}$ & $64.570^{\text {ns }}$ & $312.713^{*}$ & $791.591^{*}$ & $0.756^{\text {ns }}$ & $14.868^{*}$ \\
Radial distance (B) & 3 & $27.620^{\text {ns }}$ & $11.500^{\text {ns }}$ & $31.064^{\text {ns }}$ & $29.571^{\text {ns }}$ & $0.260^{\text {ns }}$ & $1.531^{*}$ \\
A x B & 9 & $32.573^{\text {ns }}$ & $23.186^{\text {ns }}$ & $18.647^{\text {ns }}$ & $112.403^{*}$ & $0.466^{\text {ns }}$ & $0.707^{*}$ \\
Residue & 48 & 24.993 & 23.407 & 18.894 & 38.547 & 0.461 & 0.075 \\
Total & 63 & - & - & - & - & - & - \\
CV (\%) & - & 6.90 & 7.38 & 6.10 & 8.77 & 6.43 & 1.31 \\
\hline
\end{tabular}

* Significant by Test $\mathrm{F}$ at $5 \%$ probability; $\mathrm{ns}$ - Not significant.

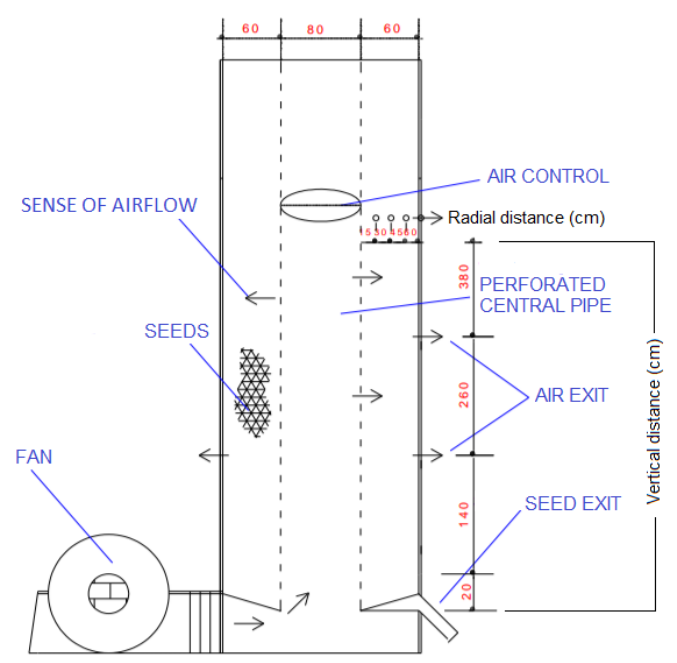

Fig 1. Representation of the fixed-bed dryer silo with radial air distribution and respective radial and vertical distances. Adapted from Peske and Villela (2003).

Table 2. Regression and Determination coefficients of equations adjusted for the water contents found in soybean seeds from different radial distances of the fixed-bed dryer.

\begin{tabular}{lccccc}
\hline & & \multicolumn{3}{c}{ Regression coefficients * } \\
\cline { 3 - 5 } Radial Distance & $(\mathrm{m})$ & $\mathrm{b}_{3}$ & $\mathrm{~b}_{2}$ & $\mathrm{~b}_{1}$ & $\mathrm{~b}_{0}$ \\
\hline 0.15 & & -0.306 & 1.860 & -2.309 & 20.524 \\
0.30 & -0.555 & 3.291 & -3.987 & 1.00 & 19.730 \\
0.45 & -0.303 & 1.848 & -2.452 & 20.874 & 1.00 \\
0.60 & -0.204 & 1.244 & -1.579 & 1.00 & 20.872 \\
\hline
\end{tabular}

*Significant by Test t at $5 \%$ probability.

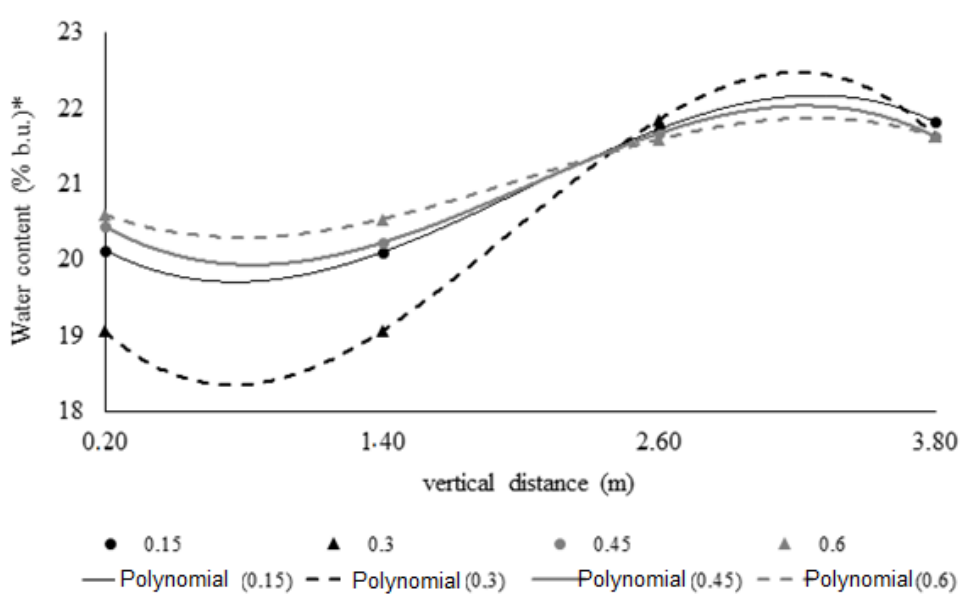

Fig 1. Influence of vertical and radial distances without water content of dried seeds in a fixed-bed dryer. *Transformed data into $\arcsin v((\times / 100))$. 


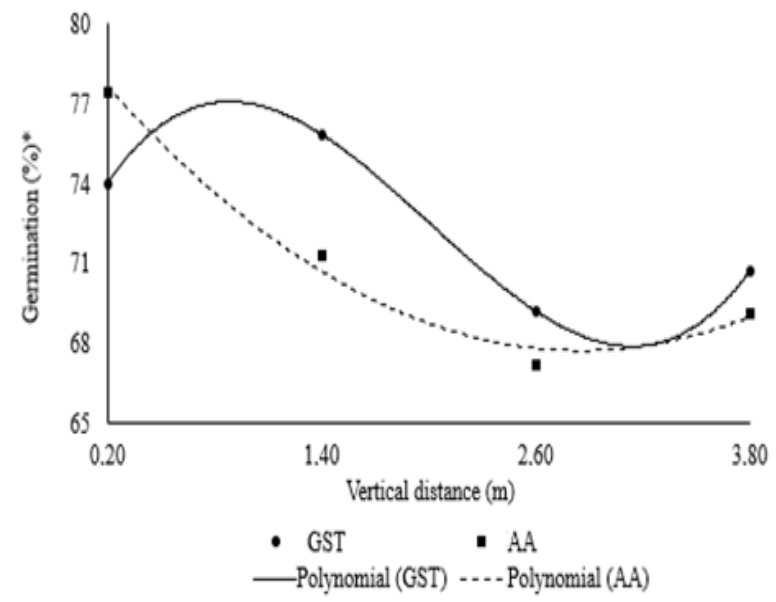

Fig 2. Influence of vertical distance on the germination test (GST) and Accelerated Aging (AA) of dry soybean seeds in a fixed-bed dryer. * Transformed data into arc sin $\vee((\times / 100))$.

Table 3. Regression and determination of coefficients of the adjusted equations for the Germination Standard (GST) and Accelerated Aging (AA) of soybean seeds from different vertical distances of the fixed-bed dryer.

\begin{tabular}{|c|c|c|c|c|c|}
\hline \multirow{2}{*}{ EVariable } & \multicolumn{4}{|c|}{ Regression coefficients $*$} & \multirow{2}{*}{$\mathrm{R}^{2}$} \\
\hline & $b_{3}$ & $b_{2}$ & $\mathrm{~b}_{1}$ & $\mathrm{~b}_{0}$ & \\
\hline GST & 1.599 & -9.650 & 13.311 & 71.751 & 1.00 \\
\hline AA & - & 1.406 & -8.023 & 79.195 & 0.98 \\
\hline
\end{tabular}

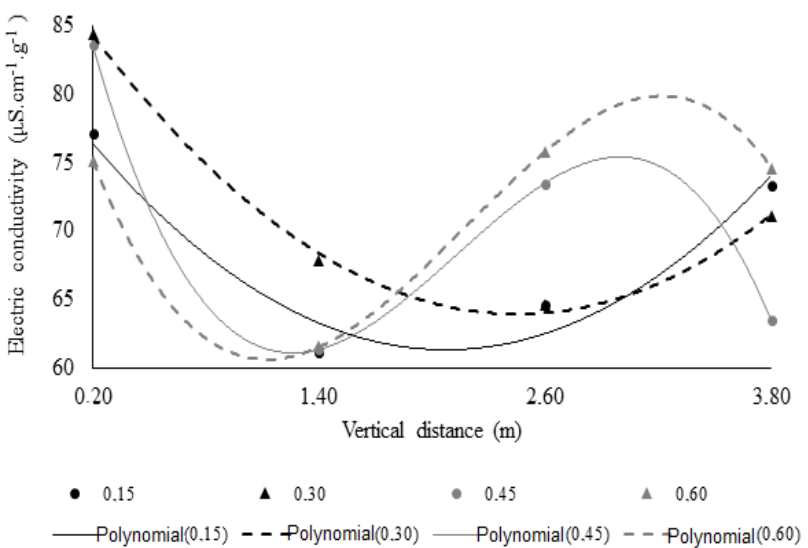

Fig 3. Influence of vertical and radial distances on the electric conductivity of dried soybean seeds in fixed-bed dryer.

Table 4. Coefficients of regression and of determination of the equations adjusted for the electrical conductivities in soybean seeds at different radial distances of the fixed-bed dryer.

\begin{tabular}{|c|c|c|c|c|c|}
\hline \multirow{2}{*}{ Radial distance (m) } & \multicolumn{4}{|c|}{ Regression coefficients * } & \multirow{2}{*}{$\mathrm{R}^{2}$} \\
\hline & $b_{3}$ & $b_{2}$ & $\mathrm{~b}_{1}$ & $b_{0}$ & \\
\hline 0.15 & - & 4.285 & -17.784 & 79.761 & 0.94 \\
\hline 0.30 & - & 4.014 & -19.671 & 88.011 & 0.99 \\
\hline 0.45 & -5.450 & 34.833 & -61.847 & 94.610 & 1.00 \\
\hline 0.60 & -4.183 & 27.236 & -45.323 & 83.079 & 1.00 \\
\hline
\end{tabular}

* Significant by $\mathrm{t}$ Test at $5 \%$ probability.

This region is located at the bottom of the dryer silo and its temperature does not exceed $43{ }^{\circ} \mathrm{C}$. The values of the equation coefficients for GST and AA as a function of the vertical distances and their respective determination coefficients $\left(R^{2}\right)$ were indicated in Table 3.

Many authors did not verify statistical differences, considering the quality of seeds before storage (immediate damages), in function of distances, temperatures and drying times. However, Garcia et al. (2005) evaluated the effects of station drying using forced ambient air on the physiological quality of wheat seeds harvested with $17.8 \%(\mathrm{bu})$ and dried up to $13 \%$ (b.u). They noted that there was no significant effect on germination, acceleration aging and electric conductivity in the seeds after drying. 
Avelar et al. (2011), carried out similar studies on soybean seeds. Their objective was to monitor the drying process uing dehumidified air by cooling. The seeds were dried in a fixed bed dryer with radial distribution of the air flow, removing its moisture by cooling and then heating to $33^{\circ} \mathrm{C}$. After germination test, first germination count and accelerated aging, they observed that there was similarity in the physiological quality of the seeds at different heights and distances, while no physiological loss was occurred.

The absence of physiological effects on seeds due to positioning in the mass was also observed in stationary drying with radial flow by Garcia et al. (2005); Levien (2005). Corroborating with these studies, Smaniotto et al. (2012) evaluated the drying of soybean seeds at different temperatures and observed that values between $40{ }^{\circ} \mathrm{C}$ and $70{ }^{\circ} \mathrm{C}$ for drying did not affect the germination of the seeds. The germination rate was higher than $85 \%$, compatible with the results found in this study (untransformed data).

It is worth mentioning that there was a split in the percentage of germination between the first twice heights and the two finals and that values of all means are as required (> $80 \%$ ) by the Ministry of Agriculture to market the seeds of the legume in question (Brasil, 2009).

This division can be attributed to fact that the drying front action did not act uniformly on the grain mass, because the seeds close to the airflow may have undergone a more effective drying procedure, decreasing its water content and its metabolism too. Garcia et al. (2004), affirmed that drying of seeds contributes to preservation of its physiological quality. Likewise, Peske and Villela (2006) added that the high water content accelerates the deterioration process, recommending the artificial drying.

Analyzing of averages of accelerated aging (Figure 2), the vertical distance of $0.20 \mathrm{~m}$ resulted in a higher mean value (94.25\%, without transformation). The vertical distance of $2.60 \mathrm{~m}$ provided the lowest value $(84.75 \%$, without transformation). This variation between the means of accelerated aging is because of the sensitivity of vigor tests in diagnosis of seed quality. Consequently, they show larger significant differences among the evaluated lots when compared with viability tests (Freitas et al. 2011a).

We observed that the distances of $0.20 \mathrm{~m}$ and $1.40 \mathrm{~m}$ were those that presented higher means of vigor by the accelerated aging test. Silva et al. (2010) stated that aging test can determine the performance of different seed lots exposed to high temperatures. We also noticed the tests that best behave under adverse conditions. Another point was the absence of uniformity in the physiological tests, particularly AA, which obtained a variation of 7.25 percentage points between the averages in the distances of $0.20 \mathrm{~m}$ with $94.25 \%$ and $3.8 \mathrm{~m}$ with $87 \%$ (unpublished data). Miranda (1999), Cavariani et al. (1999) and Garcia et al. (2005) obtained similar results.

Miranda et al. (1999) evaluated the quality of soybean seeds in different flows and temperatures in a dryer silo with radial airflow. They observed a qualitative reduction in the tests of accelerated aging and germination. In addition, we found that, although the mass reached values higher than $43^{\circ} \mathrm{C}$, it considered to be harmful in several cases (Peske and Villela, 2003; França neto et al., 2007; Silva et al., 2008). The physiology of seeds more impaired whatever they placed far away from the central core, in which lower temperatures caused higher water contents. In contrast, the closest seeds to the inflated air with higher temperature showed lower water content. Concluding that, temperature control alone does not guarantee the preservation of the physiological performance of the seeds.

In relation to $\mathrm{EC}$, it is worth mentioning that the quality of the seeds evaluated by this test is inversely proportional to the values obtained. This means that at higher EC values, the seed membranes are poorly structured, reducing their physiological quality. In spite of the unevenness of the EC means found in this study (Figure 3), it is noteworthy that the highest values are in the lower part of the silo (in 0.15 , $0.30 \mathrm{~m}$ and $0.45 \mathrm{~m}$ ) radial distance, at a vertical distance of $0.20 \mathrm{~m}$, which is the most damaging to the seeds when compared to other vertical distances. Table 4 shows the values of the coefficients of equation generated for EC at each radial distance and their respective determination coefficients $\left(R^{2}\right)$.

Smaniotto et al. (2012) reported an augment in the electrical conductivity values with increasing drying temperature, evidencing a greater release of exudates due to the intensity of disorganization of the cell membrane systems. Cavariani et al. (1999), affirmed possible changes in lipids associated with the primary cause of the damages produced by high temperatures.

In this way, we can affirm that in the vertical height of 0.20 $\mathrm{m}$ the intensity of drying temperature negatively influenced the vigor of the seeds according the test in question. However, at $3.80 \mathrm{~m}$ in height (vertical distance), the electrical conductivity was improved when the radial distance of $0.45 \mathrm{~m}$ was evaluated, since it gave a lower average value of $63.50 \mu \mathrm{S} . \mathrm{cm}^{-1} \cdot \mathrm{g}^{-1}$, in relation to other radial distances. In the same region, the highest water content was diagnosed (13.58\% b.u) (without transformation).

In a parallel between Figures 1 and 3, a close relationship between drying intensity, water content and electrical conductivity is generally evident, especially at a vertical height of 0.20 meters and a radial distance of 0.30 meters which obtained the lowest water content $(10.66 \%$, without transformation) and higher mean in electrical conductivity $\left(84.42 \mu \mathrm{S} . \mathrm{cm}^{-1} . \mathrm{g}^{-1}\right)$, respectively. This demonstrates that this location had a higher intensity drying, WC reduction and higher EC.

Several studies have demonstrated the connection between electrical conductivity, water content and tolerance to drying in soybean seeds. Vieira et al. (2002) reported that the initial water content of soybean seeds might influence the interpretation of results of the electrical conductivity test, verifying that the EC readings are decreased when the water content of the seeds increased.

Correlating with temperature, Veiga et al. (2007) evaluated the desiccation tolerance of soybean seeds submitted to artificial drying. Although they have been harvested with a high water content ( $50 \%)$, the seeds were submitted to drying counted higher EC values to those that did not go through the process. Rosa et al. (2000) and Ribeiro et al. (2009) verified similar results in corn seeds, and Fessel et al. (2010) in soybean seeds, correlating high temperatures with high EC values.

Another characteristic observed in the electrical conductivity test were inverse results to those of GST and AA (Figure 2), when it compared at the same vertical distance $(0.20 \mathrm{~m})$. The height in question stood out with high germination (91.62\%) and EV (94.25\%) (Unprocessed data) and, thus, 
divergent with EC $\left(84.42 \mu \mathrm{S} . \mathrm{cm}^{-1} \cdot \mathrm{g}^{-1}\right)$. Although AA is also a vigor test as EC, such differences in the behavior of treatments with similar germination can be explained by the fact that the first changes in biochemical processes associated with deterioration generally occur before the decline in germination capacity. The fall of germinative power is an important indication of quality loss, but it is the last consequence of quality deterioration (BRASIL, 2009).

Antunes et al. (2016) Dias and Marcos Filho (1996), analyzed soybean seeds and verified that highest values of EC corresponded to the lowest percentages of germination, showing that this is a good indicator of the physiological potential of seeds. However, the drying factor has not been indicated in the studies cited above. When soybean seeds were submitted to different temperatures, the germination drop could not be detected by the electrical conductivity in some lots. Fessel et al. (2010) verified inverse relationship. Smaniotto et al. (2012) reported that even with the increase of drying temperature and EC, there was no reduction in germination, and it varies between $40{ }^{\circ} \mathrm{C}$ and $70{ }^{\circ} \mathrm{C}$, respectively. Barbieri et al. (2013) also detected divergence between electrical conductivity and germination.

Vigor tests whose principles are based on integrity of cell membranes deserve to be highlighted, as they enable the detection of the process of seed deterioration in its initial phase (Delouche and Baskin, 1973). Therefore, in many cases, significant differences in germination or even their relationship with electrical conductivity have not seen at the beginning (immediate effects), but rather at the end (latent effects) of storage period. In this way detecting possible future losses caused by drying (Garcia et al., 2005, Campos et al., 2012, Silva et al., 2011).

In general, although the averages showed disorder when the the radial distances $\left(0.60 \mathrm{~m}\right.$ with $\left.74.6 \mu \mathrm{S} . \mathrm{cm}^{-1} \cdot \mathrm{g}^{-1}\right)$ and vertical ones $\left(0.20 \mathrm{~m}\right.$ with $\left.77.08 \mu \mathrm{S} . \mathrm{cm}^{-1} \cdot \mathrm{g}^{-1}\right)$ were fixed (Figure 3), the values were in agreement with Vieira (1994), determined lots that presenting EC of $60-70 \mu \mathrm{S} . \mathrm{cm}^{-1} \cdot \mathrm{g}^{-1}$ as high vigor and between 70 a $80 \mu \mathrm{S} . \mathrm{cm}^{-1} \cdot \mathrm{g}^{-1}$ for soybean seeds. They are considered to be of medium force.

Some aspects of great relevance justify such discrepancies. The analyzed seeds were harvested by large machines under real conditions of temperature and relative humidity. They could be susceptible to precipitation, depot in the field for long periods and/or abrupt changes in the climate as characteristics of period in question. They even might contain mixtures between cultivars.

In general, all these issues can influence any result, given the fact that there is often no effective control in the preservation of physical and physiological quality in every process from harvest to arrival at the processing unit. This is more evident when it comes to large-scale production, where in most cases, only GST serves as a test to determine the lots considered suitable for commercialization (Vieira and Kryzanowski, 1999; França neto et al., 2007; Carvalho et al., 2009; Krzyzanowski et al., 2008b; LopeS et al., 2011).

\section{Materials and methods}

\section{Variety specifications}

In this work, soybean seeds of BMX Power variety were harvested and evaluated in the period of March in the Municipality of Abadiânia, GO, and processed in the Seed
Processing Unit of the Company Food Products Orlândia S/a Com Ind - Food located in Anápolis, GO .

The BMX Power variety is ideal for opening high productive potential, stability, good behavior on floodplains and has a habit of indeterminate growth, high resistant lodging.

\section{Dryer description and sample collection}

The seed samples were distributed in a fixed bed dryer with radial air distribution, in which it had 6 meters of height, 1 meter of radius, maximum capacity of $11400 \mathrm{~kg}$ and air flow of $18000 \mathrm{~m}^{3}$ air / ha and temperature of $40{ }^{\circ} \mathrm{C}$. The seeds were collected from different places of the dryer, in which they already had sampling points. So, the collections were made, both vertically; $0.2 ; 1.4 ; 2.6$ and 3.8 meters in relation to the base containing seeds, as well as radially $0.15,0.30$, 0.45 and 0.60 meters duly distributed in relation to the perforated central duct (Figure 1) of the dryer which was used a suitably adapted sampler. The vertical and radially distances represent the dimensions of the silo (height and diameter) respectively, representing the location of the seeds in the inner part of the silo

Sampling was performed after drying ended after 4 hours, with seeds having a water content of $13 \%$ wet basis (b.u.).

\section{Experimental Design}

The experimental design was completely randomized in a $4 \times 4$ factorial scheme where the treatments evaluated were the 4 vertical distances $(0.20,1.40,2.60$ and $3.80 \mathrm{~m})$ and radially $(0.15,0.30,0.45$ and $0.60 \mathrm{~m})$ from the seed collections in the dryer.

\section{Evaluation tests}

After 3 days of collection, seeds were sent to the Laboratory of Drying and Storage of Vegetable Products, located at the State University of Goiás - UEG / CCET located in Anápolis, where the following tests were applied:

Water Content (WC): The method used to determine the water content of the seeds, the greenhouse method at $105 \pm$ 3으 for 24 hours, according to Brazil (2009), using 4 replicates of 10 grams each.

Germination Standard Test (GST): We used 4 replicates of 50 seeds distributed on 2 germitest sheet papers covered with a third making rolls. The papers were previously moistened with distilled water equal to 3 times the paperweight. The rolls were then placed in a germinator at a constant temperature of $25{ }^{\circ} \mathrm{C}$. The normal seedlings were counted on the eighth day after the test, and the data were expressed as a percentage (Brasil, 2009).

First Germination Count (FGC): It was carried out together with GST, computing the percentage of normal seedlings obtained on the fifth day after assembling the test, evaluating the vigor and with data expressed as a percentage (Brasil, 2009).

Accelerated Aging (AA): This was conducted by placing samples in 4 gerbox boxes divided into compartments where the seeds were distributed on an aluminum screen at the top. In the bottom part, $40 \mathrm{ml}$ of distilled water was placed to maintain the relative humidity of the air inside each gerbox at $100 \%$. The gerboxes were closed in a type B.O.D chamber at a temperature of $41{ }^{\circ} \mathrm{C}$ for 48 hours. Then, 50 
seeds of each gerbox were collected and the standard germination test was performed as previously described. On the fifth day, the percentage of normal seedlings was quantified (Vieira and Krzyzanowski, 1999).

Electrical Conductivity (EC): As described by Vieira and Krzyzanowski, (1999) the test was carried out by collecting 4 samples of 50 seeds, duly weighed and placed in sanitized containers containing $75 \mathrm{ml}$ of distilled water. After the 24hour period at a temperature of $25^{\circ} \mathrm{C}$, the electrical conductivity was measured through a conductivity meter, the results were expressed in $\mu S \cdot \mathrm{cm}^{-1} \cdot \mathrm{g}^{-1}$.

Germination Speed Index (GSI): This test was performed with 200 seeds and 4 replicates containing 50 seeds each. It was established in conjunction with the germination test, according to the requirements of the Rules for Seed Analysis (BRASIL, 2009). At the end of the test, with the daily data of the number of normal seedlings, the germination speed was calculated using the equation proposed by Maguire, (1962) apud Nakagawa (1999a).

\section{Statistical Analysis}

The data were submitted to analysis of variance and $\mathrm{F}$ test at $5 \%$ of probability. Because they were mostly percentage data (for the WC, GST, FCT and AA) the transformation was used in $\operatorname{arc} \sin V((\times / 100))$. When the $F$ test pointed to significant characteristics, it used regression analysis, where to choose the regression models $\left(b 2 \cdot x^{2}+b 1 . x+b 0\right)$ or cubic regression (b3. $\left.x^{3}+b 2 \cdot x^{2}+b 1 . x+b 0\right)$ according the significance of Test $t$ (5\%) for each regression coefficient. Statistical analyzes were performed using Sisvar 5.1 software.

\section{Conclusion}

In stationary drying, super drying occurs in the lower layer and retardation in the upper layer. Seeds located at vertical heights of 0.2 and $1.4 \mathrm{~m}$ obtained the highest mean GST and accelerated aging. The seeds located at a vertical height of $0.2 \mathrm{~m}$, regardless of the radial distances, showed less vigor by the electrical conductivity test in relation the other treatments. The variables FCT and GVI were not significantly influenced by the evaluated treatments and their interaction.

\section{References}

Almeida CA, Cardoso neto J, Seleme R, Schilipack ECS, Alvez (2013) Mathematical modeling and simulation to optimize the flow of Brazilian soybeans exported to China. Accounting and Economics, Joaçaba, 12(1): 199-225.

Antunes AM, Devilla IA, Neto ACB, Alves BGX, Alves GR, \& Santos MM (2016) Development of an automated system of aeration for grain storage. African Journal of Agricultural Research, 11(43): 4293-4303.

Avelar SAG, Levien AM, Peske ST, Villela FA, Baudet L (2011) Stationary drying of soybean seeds with dehumidified air by cooling. Braz J Seeds. 33(3):454-462.

Avelar SA, Villela FA, Peske ST (2012) Advances in seed drying-use of dehumidified air by cooling. Revista Seed News, Ago.
Barbieri APP, Mattioni NM, Haesbaert FM, Andrade FF, Cabrera IC, Mertz LM (2013) Individual electrical conductivity test in soybean seeds and the relationship with emergence of field seedlings. Interciência Magazine. 38(4):310-315.

Brasil (2009) Ministério da Agricultura e Reforma Agrária. Regras para Análise de sementes. Brasília, DF. 398p.

Campos RC, Resende O, Oliveira DEC (2012) Evaluation of the physiological quality of soybean seeds submitted to the aeration process in metallic silos. In: Congresso Brasileiro de Pesquisa e Pós-graduação do Campus Rio Verde do Ifgoian 1. Rio Verde, Instituto Federal de Educação, Ciência e Tecnologia Goiano - Campus Rio Verde, nov.

Carvalho LF, Sediyama CS, Reis MS, Dias DCFS, Moreira MA (2009) In creep of the soaking temperature of the soybean seed in the electrical conductivity test to evaluate the physiological quality. Braz J Seeds. 31(1):9-17.

Carvalho NM, Nakagawa J (2000) Sementes - Ciência, tecnologia e produção. 4. ed. rev. e ampl., Jaboticabal: Funep, p.588.

Cavarianl C, Silva WR, Miranda LC, Nakagawa J, Bergiorno DC (1999) Stationary drying of corn seeds with radial distribution of air flow. II. Andamento físico. Braz J Seeds. 21(1):7-17.

Cavariani C, Silva WR, Miranda LC, Nakagawa J, Belgiorno DC (1998) Stationary drying of corn seeds with radial distribution of air flow. I. Physiological quality of seeds. Braz J Seeds. 20(2):194-201.

Dall'agnol A, Lazarotto, Hirakuri MH (2010) Desenvolvimento, Mercado e Rentabilidade da Soja Brasileira. Londrina, PR: Embrapa Soja, abr. 18p.

Delouche JC, Baskin CC (1973) Accelerated aging techniques for predicting the relative storability of seed lots. Seed Sci Technol. 1(2):427-452.

Dias DCFS, Marcos filho J (1996) Testes de condutividade elétrica para avaliação do vigor de sementes de soja (Glycine max (L.) Merrill). Scientia Agrícola. 53(1):31-42.

Eiras DL (2013) Perda da matéria seca em grãos de milho submetidos a sistemas de secagem natural e artificial. 2013. 61p. Dissertação (Mestrado em Agronomia)Faculdade de Ciências Agronômicas, Universidade Estadual de São Paulo, Botucatu.

Fessel SA, Panobianco M, Souza CR, Vieira RD (2010) Electrical conductivity test on soybean seeds stored under different temperatures. Bragantia. 69(1):207-214.

França neto JB, Krzyzanowski FC, Henning AA, Pádua GP (2010) High quality soybean production technology. Londrina, PR .20(3):26-32. Abrates.

França neto JB, Krzyzanowski FC, Pádua GP, Costa NP, Henning AA (2007) Tecnologia da produção de semente de soja de alta qualidade - Série Sementes. Londrina, PR: Embrapa Soja, mar.12p.

Freitas ICV, Nunes JEGJ, Segundo JP, Vilarinho MS (2011) Germination and vigor of soybean seeds classified in different sizes. Agropecuária Técnica. 32(1):108-114.

Freitas MCM (2011) A cultura da soja no Brasil: O crescimento da produção brasileira e o surgimento de uma nova fronteira agrícola. Centro Científico Conhecer, Goiânia. 17(12).

Garcia DC, Barros ACSA, Peske ST, Menezes NL (2001) Stationary drying of wheat seeds with forced ambient air. Braz J Seeds. 23(2):275-280. 
Garcia DC, Barros ACSA, Peske ST, Menezes NL (2005) hysiological quality of wheat seeds submitted to stationary drying with forced ambient air. Braz J Seeds. 27(1):158166.

Garcia DG, Barros ACSA, Peske ST, Menezes NL (2004) Secagem de sementes. Ciência Rural. 34(2):603-608.

Huttunen M, Holmberg A, Stenstrom S (2017) Modeling fixed-bed drying of bark drying. Department of Chemical Engineering Lund University. 35(1):97-107.

Krzyzanowski FC, França neto JB, Henning AA, Costa NP (2008) Quality control adding value to soybeans - Seeds Series. Londrina, PR: Embrapa Soy, jan. a. 12p.

Krzyzanowski FC, França neto JB, Henning AA, Costa NPO (2008) Soybean seed as technology and basis for high productivity - Seeds Series. Londrina, PR: Embrapa Soy, abr. b. $8 p$.

Levien AM (2005) Secagem estacionária de sementes de soja utilizando ar de secagem com variações na umidade relativa. 30p. Dissertação (Mestre em Ciência e Tecnologia de Sementes) Faculdade de Agronomia "Eliseu Maciel", Universidade Federal de Pelotas.

Lopes MM, Prado MOD, Sader R, Barbosa RM (2011) Mechanical and physiological effects on soybean harvesting and processing. Biosci J. 27(2):230-238.

Marcos filho J, Carvalho RV, Cícero SM, Demétrio CGB (1986) Qualidade Fisiológica e comportamento de sementes de soja (Glycine max (I.) merrill) no armazenamento e no campo. Anais da Escola Superior de Agricultura "Luiz de Queiroz". Piracicaba, 43:195-249.

Moraes MLB de (2000) Comportamento da pressão estática e da frente de secagem em uma coluna de sementes de arroz. 50f. Tese (Doutorado em Ciência e Tecnologia de Sementes) - Universidade Federal de Pelotas, Pelotas.

Nakagawa J (1999) Seed performance-based vigor test. In: Krzyzanowski FC, Vieira RD, França neto JB Seed vigor: concepts and tests. Londrina, Abrates: a.

Nakagawa J Vigor tests based on seedling evaluation. In: Vieira RD, Carvalho NM (ed.) (1999) Seed vigor tests. Jaboticabal: FUNEP, b. p.49-85.

Pasin NH (1991) Static drying of soybean seeds. Abrates, Londrina, 2(1):33-39.
Peske ST, Villela FA Secagem de sementes. In: Peske ST, Rosenthal MDA, Rota GRM (2003) Seeds: Scientific and Technological Foundations. Pelotas. p.281-319.

Peske ST, Villela FA Seed drying. In: Peske ST, Lucca filho OA, Barros AC (2006) Seeds: scientific and technological foundations. 2 ed. Pelotas, 332p.

Pimentel Gomes F (2002) Course of experimental statistics. São Paulo: Nobel.

Randa LC, Silva WR, Cavariani C (1999) Drying of soybean seeds in silo with radial distribution of air flow: I. Physical Monitoring. Brazilian Agricultural Research, Brasília, v.34, n.11, p.2097-2108,

Rosa SDVF, Pinho EVRV, Vieira MGGC, Veiga RD (2001) Efficacy of the electrical conductivity test for studies of drying damages in corn seeds. Braz J Seeds. 22(1):54- 63.

Silva JB, Lazarini E, Sá ME (2010) Behavior of soybean cultivars submitted to different periods of accelerated aging. Biosci J. 26(5):755-762.

Silva SSJ, Afonso ADL, Donzelles SML, Nogueira RM Drying and Drying. In: Silva JS (2008) Drying and storage of agricultural products. 2 ed. Viçosa: Aprenda Fácil, p.109146.

Silva TTA, Oliveira JA, Carvalho MLM, Vieira AR, Costa RR, Abreu LAS (2011) Harvest water content and drying temperature as sorghum seeds during storage. Braz JCorn Sorgh. 10(1):66-81.

Smaniotto TAS, Resende O, Oliveira DEC, Sousa KA, Kester AN, Bessa JFV (2012) Physiological quality of soybean seeds during drying. In: Congresso de Pesquisa e Pósgraduação do Campus Rio Verde do Ifgoiano 1. Rio Verde, Anais. Rio Verde: Instituto Federal de Educação, Ciência e Tecnologia Goiano. 1: p.1-3.

Veiga AD, Rosa SDVF, Silva PA, Oliveira JA, Alvim PO, Diniz KA (2007) Soil seed tolerance to desiccation. Agrotechnology Science Magazine. 31(3):774-280.

Vieira RD (1994) Electrical conductivity test. In: VIEIRA, R. D.; CARVALHO, N. M. Seed vigor tests. Jaboticabal: Funep, p. 103-132.

Vieira RD, Penariol AL, Perecin D, Panobianco M (2002) Electrical conductivity and initial water content of soybean seeds. Braz Agric Res Brasília. 37(9):1333-1338. 